\title{
Experimental Study the role of LasA Protease of Pseudomonas aeruginosa in the Treatment of Bacterial Keratitis Caused by Staphylococcus aureaus
}

\author{
Aida H. Al - saa'edi* \\ Munera CH. Al - Abaadi** \\ Jassim M. Karhoot*** \\ Samira A. Funtil****
}

\author{
BVM \& MSc \\ PhD \\ PhD \\ BSc
}

\begin{abstract}
Summary:
Background: LasA protease play a major role in the colonization of the bacteria to the cornea during bacterial keratitis by preventing other bacteria from colonization to the cornea, for example in the mixed infection with S. aureus the enzyme eradicate the bacteria by their lysis it and finally eliminate the competitive for P. aeruginosa bacteria.

Objective: To study the role of LasA protease of Pseudomonas aeruginosa in the treatment of experimental keratitis caused by S. aureus.

Patients and methods: One hundred - twenty clinical samples (corneal scraping) were collected from patients suspected with bacterial keratitis presenting to Ibn Al-Haitham Teaching Hospital from May 2013 until November 2013. The bacterial isolate of P. aeruginosa that harbored LasA gene and capable of production of enzyme was analyzed by Real - time PCR. LasA protease enzyme was extracted by cold centrifugation and purified by gel - filtration chromatography.

Results: The results of the experimental treatment of bacterial keratitis (in vivo) of infected rabbits eyes caused by S. aureus has showed that the efficacy of LasA protease was effective as Lysostaphin drug in eradicating the S.aureus from the infected corneas. While Vancomycin drug gave very little potency in the eradicating S. aureus from corneas in comparison with potency of LasA protease and Lysostaphin during this time but showed good potency with very late period ( approximately after 3 days) after application of treatment.

Conclusion: The current study revealed that the LasA protease efficacy in the experimental treatment of bacterial keratitis of rabbit's eye corneas was good and similar to that of Lysostaphin in eradicating S. aureus from corneas of these animals and was higher than that of Vancomycin.

Key words: LasA protease, treatment of bacterial keratitis, S. aureus.
\end{abstract}

\section{Introduction:}

Pseudomonas aeruginosa produces several proteases and toxins, the best characterized being exotoxin, elastase (LasB), LasA protease, alkaline protease and protease IV. Proteases enzymes are important predisposing factors that's mediates the establishment of bacterial infection and enhanced damage to the corneas $(1,2,3)$.

LasA protease (also called staphylolysin) is a $20 \mathrm{kDa}$ and elastolytic and staphylolytic endopeptidase that are secreted by P.aeruginosa. LasA protease play a major role in the colonization of the bacteria during bacterial keratitis by preventing other bacteria from colonization to the cornea, for example in the mixed infection with $\mathrm{S}$. aureus the enzyme eradicate the bacteria by lysis it and finally eliminate the competitive bacteria for P. aeruginosa (4). LasA protease can

*Corresponding Author: College of Veterinary / University of Baghdad Aomahmed_2006@yahoo.com

**College of Science/ University of Baghdad

***College of Medicine / University of Baghdad

****College of Science, Ministry of Science \& Technology cause lysis of a wide range of). S.aureus strains, and it has also been shown to inhibit the growth of $\mathrm{S}$. aureus cells in vitro $(5,6)$. This favor LasA protease as another useful agent in enzyme - based treatment of S.aureus infections. LasA protease is not a major virulence factor in experimental P. aeruginosa keratitis $(7,8,9)$.

\section{Patients and methods:}

Specimens collection: One - hundred and twenty patients with suspected microbial keratitis (corneal ulcer) presenting to Ibn Al-Haytham Teaching Eye Hospital, from May 2013 to November 2013, were included in this study. Corneal scraping was done by an ophthalmologist using a sterile bent-tipped needle.

Isolation :The corneal scraping was inoculated onto 4 types of cultural media: which were included: Blood agar inoculated (aerobically and an aerobically)for detecting the type of haemolysis, MacConkey agar to differentiate organisms according to their ability to ferment lactose, Chocolates agar 
for detecting fastidious organisms, then were incubated at $37^{\circ} \mathrm{C}$ for $24 \mathrm{~h}$ and finally inoculated onto Sabouraud's dextrose agar for detecting fungal agents incubated at $28^{\circ} \mathrm{C}$ and $37^{\circ} \mathrm{C}$ for 24 $72 \mathrm{~h}$ for yeast and four week for mold detection (10).

Identification: Bacterial identification was performed by using biochemical tests. These include Gram reaction, growth characteristics, and other test methods such as oxidase and catalase tests.

Conformation: By Vitek 2 Compact system (The mentioned tests; along with the Vitek Compact 2 System confirmed that the isolates belonged to Pseudomonas aeruginosa).

Real - time PCR analysis of Pseudomonas aeruginosa isolates showed that only one isolate harbored LasA gene and was named as (P85).

\section{Purification steps of LasA enzyme:}

Preparation of crude LasA enzyme: For the purpose of the production of the enzyme, the bacterial isolate of P.aeruginosa producing enzyme number (85) is activated by inoculating into tube containing lauria bertani broth (LB) at $5 \mathrm{ml}$ and incubated at $37^{\circ} \mathrm{C}$ for $18 \mathrm{~h}$. Then the bacterial growth re - incubated by adding it to flask containing lauria bertani broth at volume $300 \mathrm{ml}$ and incubated at 37 for $18 \mathrm{~h}$. The bacterial growth centrifuged by cold centrifuge at $3500 \times \mathrm{g}$ for $60 \mathrm{~min}$, then the bacterial supernatant was collected into sterile bottle at size $500 \mathrm{ml}(11)$.

Precipitation by ammonium sulfate: The ammonium sulfate was added into crude LasA enzyme at $80 \%$ saturation by adding $51.5 \mathrm{gm} / 100 \mathrm{ml}$ gradually inside ice bed with continuous movement by using magnetic stirrer for 60 minutes, and then the solution was leaved to settle for $18 \mathrm{~h}$ at $4{ }^{\circ} \mathrm{C}$. The precipitate was collected in sterile battle and keeps it at $4^{\circ} \mathrm{C}$ for next steps of purification (12).

Estimate the concentration of protein: It was done according to ( Bradford, 1976) (13) for estimating the protein and using the standard curve for bovine serum albumin ( BSA ) protein at concentrations $(1.6,1.4,1.2,1,0.8,0.6,0.4) \mu \mathrm{g} / \mathrm{ml}$ by using BSA stock

Dialysis: The extracted LasA enzyme that produced by precipitation with ammonium sulfate was loaded inside dialysis bag at molecular weight $10000 \mathrm{kDa}$. Then the ends of the dialysis bag was closed strongly and put it inside a sterile large container at size $500 \mathrm{ml}$ containing buffered phosphate ( $\mathrm{pH} 7.5$ at concentration $0.02 \mathrm{M}$ ) with continuous movement by magnetic stirrer at $4^{\circ} \mathrm{C}$ for $20 \mathrm{~h}$. (14).

Concentrated LasA enzyme: LasA enzyme was concentrated by putting the dialysis bag containing the enzyme in a sterile large container contained sucrose and leaved it for hours until the volume of dialysis bag is clearly decreased and reached to $10 \mathrm{ml}$.

Gel filtration chromatography: Chromatography was performed with a column of Sephadex G -100 equilibrated with $0.1 \mathrm{M}$ $\mathrm{KCl}$ and $\mathrm{PBS} \mathrm{pH} 7.5-8$ at approximately $4^{\circ} \mathrm{C}$. concentrated enzyme $(10 \mathrm{ml})$ was applied to the column $(2$ by $90 \mathrm{~cm})$ and eluted at a flow rate of $3 \mathrm{ml} / 4$ minutes with the equilibrating buffer $0.1 \mathrm{M} \mathrm{KCL}$. Fractions were collected into sterile tubes and we were followed protein concentration of the penetrated parts to read the absorbance at the wave length $280 \mathrm{~nm}$ by UV Spectrphotometer. Then fractions of the peaks were collected and protein concentration was determined according to the standard curve for estimation protein concentration. After the finishing of above steps the enzyme was preserved at $-20{ }^{\circ} \mathrm{C}$ for other steps (15).

\section{Treatment experiments:}

Culture condition: One clinical isolate of Methicillin Sensitive Staphylococcus aureus (MSSA) isolated from a human corneal scarping was diagnosed and confirmed the diagnosis and susceptibility by Vitek 2 Compact System in the Central Health Laboratory. This isolate was used to induce experimental keratitis. Fresh culture was prepared by inoculating the bacteria onto brain heart infusion broth at $37^{\circ} \mathrm{C}$ for $18 \mathrm{~h}$.

Induction of experimental Staphylococcus aureus keratitis (in vivo):

A total of $100 \mu \mathrm{l}$ of a freshly prepared S. aureus cell suspension was injected intrastromlly into the center of the cornea of 4 local Iraqi white rabbits with syringes of 30 - gauge and $1 \mathrm{ml}$ insulin needles and the fifth rabbit was left without injection as negative control.

Preparation of antibiotics: Lysostaphin was diluted to a final concentration of $1 \mu \mathrm{g} / \mu \mathrm{l}$ in sterile distilled water and Vancomycin was dissolved in sterile water to a final concentration of $33 \mathrm{mg} / \mathrm{ml}$ similar to that recommended for clinical use. Brain heart infusion broth used as drug for negative control.

Treatment experiment (in vivo): Following intrastromal injection of the bacterial cell suspension, the rabbits were randomly divided into treatment groups. The therapeutic regimen was performed by allowing the infection to progress undisturbed for $10 \mathrm{~h}$ prior to the initiation of therapy. Topical treatment has been done by applying $100 \mu \mathrm{l}$ partial purified LasA protease of P. aeruginosa to the infected eye of one rabbit, $100 \mu$ of Lysostaphin was applied to infected eye of second rabbit, and $100 \mu \mathrm{l}$ Vancomycin was applied to infected eye of third rabbit. All topical treatments were applied in a sequence of every $30 \mathrm{~min}$ during the first $5 \mathrm{~h}$ and then every hour for additional $10 \mathrm{~h}$. The fourth rabbit was injected with $100 \mu \mathrm{l}$ of bacterial suspension and left without treatment as positive control whereas the fifth rabbit was subjected only with topical applying of sterile brain heart infusion broth as negative control (16).

\section{Results:}

Our present study was revealed that the bacterial isolates identified as P.aeruginosa were 26(21.6\%) (Table 1) and the Real - time PCR analysis results were indicated that only one bacterial isolate of P. aeruginosa (P85) was harbored LasA protease gene at percentage $(3.8 \%)$. 
Table 1: Bacterial and fungal pathogens recovered from corneal scrapes

\begin{tabular}{ccc}
\hline Name of isolates & $\begin{array}{c}\text { Total number of } \\
\text { isolates }\end{array}$ & Percentage \\
\hline Pseudomonas aeruginosa & 26 & $21.6 \%$ \\
\hline Staphylococcus aureus & 14 & $11.1 \%$ \\
\hline Streptococcus spp. & 6 & $5 \%$ \\
\hline Morexella catarhalis & 4 & $3.3 \%$ \\
\hline Proteus spp. & 4 & $3.3 \%$ \\
\hline Escherichia coli & 3 & $2.5 \%$ \\
\hline Fungal spp. & 16 & $13.3 \%$ \\
\hline Negative culture ( no growth) & 47 & $39.1 \%$ \\
\hline Total & 120 & $100 \%$ \\
\hline
\end{tabular}

A enzyme was extracted from bacterial isolate (P85) and the resulted extracted crude enzyme concentration was measured by Bradford method (Bradford,1976) and by reference to the standard curve for BSA (Figure1), the protein concentration was reached $60 \mu \mathrm{g} / \mathrm{ml}$.

The crude enzyme $(300 \mathrm{ml})$ was precipitated by ammonium sulfate at $80 \%$ saturation, and purified by gel filtration chromatography. By testing the effectiveness of the enzyme were concentrated in the third peak and in the fractions (5258 ) with increased in the purification times ( Figure 2) and by reference to standard curve of BSA, the concentration of the enzyme was measured and reached 40 .

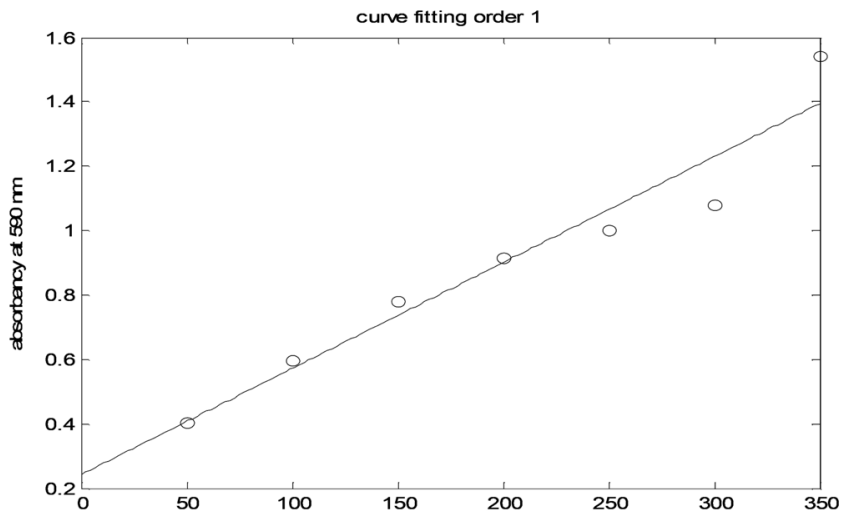

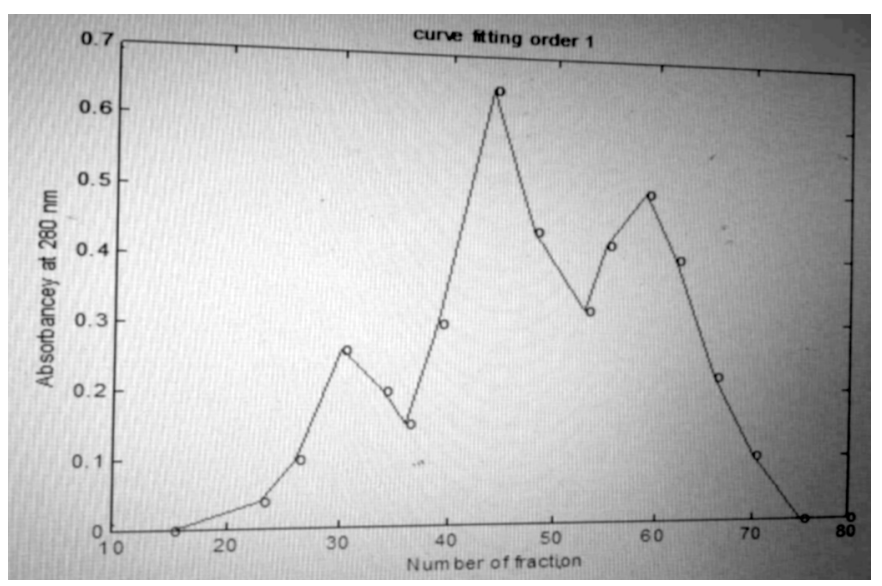

Figure (2): Gel filtration chromatography for purification of LasA protease enzyme by using column of Sephadex G-100 and eluted at a flow rate of $3 \mathrm{ml} / 4 \mathrm{~min}$ with the equilibrating buffer $0.1 \mathrm{M} \mathrm{KCl}$ and PBS pH $(7.5-8)$ at $4^{\circ} \mathrm{C}$.

Following intrastromal injection of the bacterial cell suspension, the rabbits randomly divided as treatment groups. The infection was allowed to progress undisturbed for approximately $5 \mathrm{~h}$ (Figure 3.A.B.C). Three right eyes of the three rabbits were used and treated topically with one of drugs (LasA enzyme, Lysostaphin drug, and Vancomycin drug) respectively. One eye rabbit was treated topically with LasA protease, second eye was treated with Lysostaphin, and third rabbit eye was treated with Vancomycin drug. The two eyes of the two remained rabbits, one of them was injected with bacterial suspension only and used as control positive (left without treatment), and another eye rabbit was injected only with sterile brain heart infusion broth and used as negative control ( Figure 4.A.B).

Concentration of abovine serum albumin (BSA) $\mu \mathrm{g} / \mathrm{ml}$.

Figure 1: Standard curve of bovine serum albumin ( BSA)
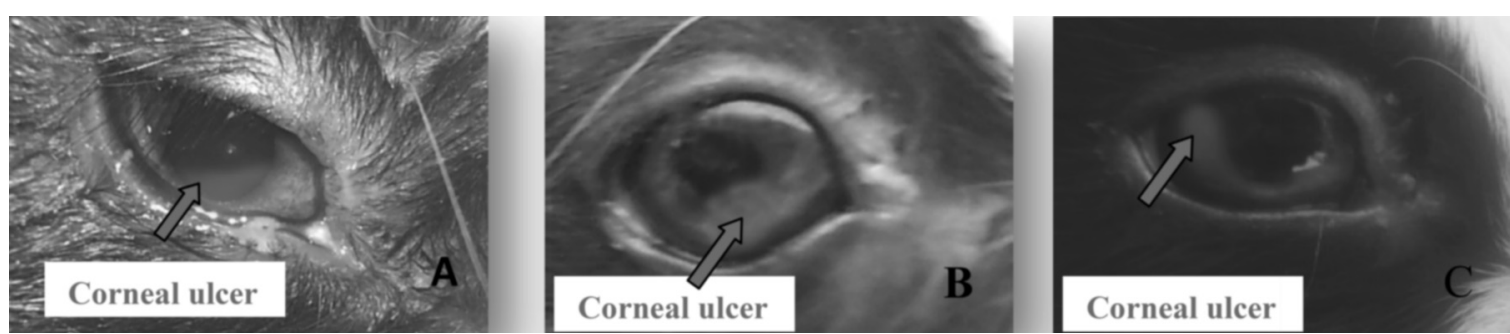

Figure ( 3. A. B. C ) : Corneal ulcer of the three right rabbits eyes that's initiated after injection with $100 \mu$ l of bacterial suspension and allowed the infection to progress for $5 \mathrm{~h}$, the three rabbits were divided randomly to treated with Las $\mathrm{A}$ protease, Lysostaphin drug and Vancomycin drug respectively. 

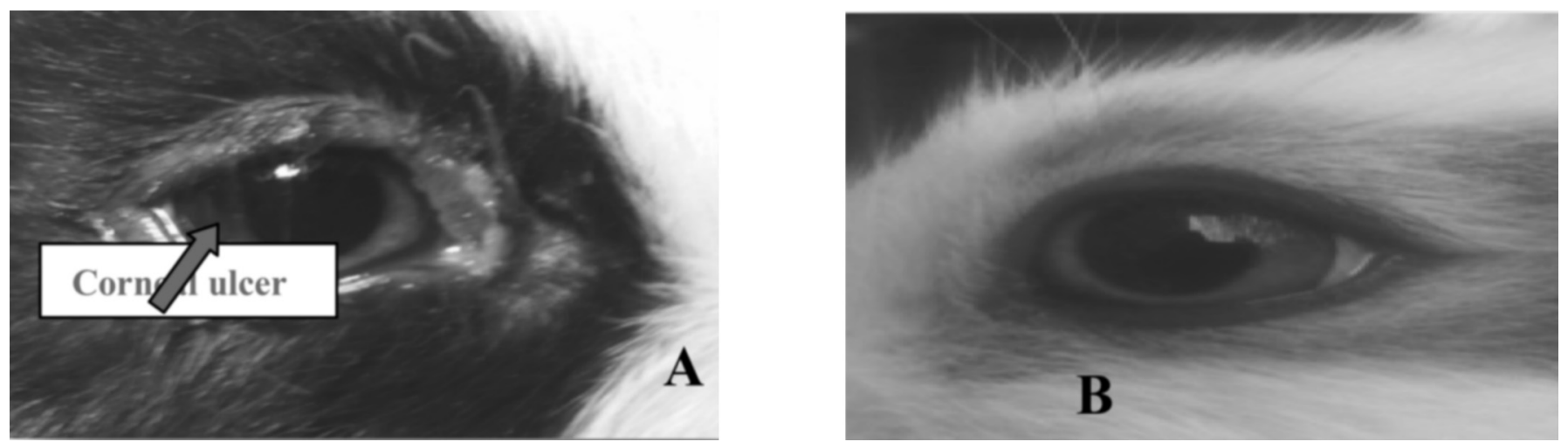

Figure (4.A.B): A. Corneal ulcer of the right eye of rabbit that's initiated after injection with $100 \mu$ l of bacterial suspension and allowed the infection to progress for $5 \mathrm{~h}$ and used as control positive of experimental treatment. B. Corneas of eye rabbit was injected with $100 \mu \mathrm{l}$ of sterile brain heart infusion broth only and used as control negative of treatment experiment.

The efficacy of LasA protease in the treatment of S. aureus induced experimental keratitis was examined by using therapy schedule which includes: early - onset treatment of experimental kertitis and late- oncet treatment of experimental keratitis . In experiments with $\mathrm{S}$. aureus strain, the effect of LasA protease was compared to that of Lysostaphin drug and Vancomycin drug. Each set of experiment included two treatment groups, together with treatment by LasA enzyme and control group (negative and positive control).

Early- onset treatment of experimental keratitis : Approximately $10 \mathrm{~h}$ after giving topical treatment, the experiment was showed that LasA protease was effective as Lysostaphin drug in treating the $\mathrm{S}$. aureus from the infected corneas during this period (Figure 5.A.B). While Vancomycin revealed very little potency in the eradicating S. aureus from corneas during this time ( Figure 5. C).

The three right eyes rabbits were subjected to late onset therapy schedule ( approximately further two days) provided a more extreme test of the efficacy of LasA protease, Lysostaphin, and Vancomycin as it allowed a longer time for confirmation of our results. We noticed that LasA and Lysostaphin remained highly effective in eradicating $\mathrm{S}$ aureus keratitis and there is no complications were seen. While Vancomycin show good results after 3 days of treatment (Figure 5.D) and all results were compared to both positive and negative control.
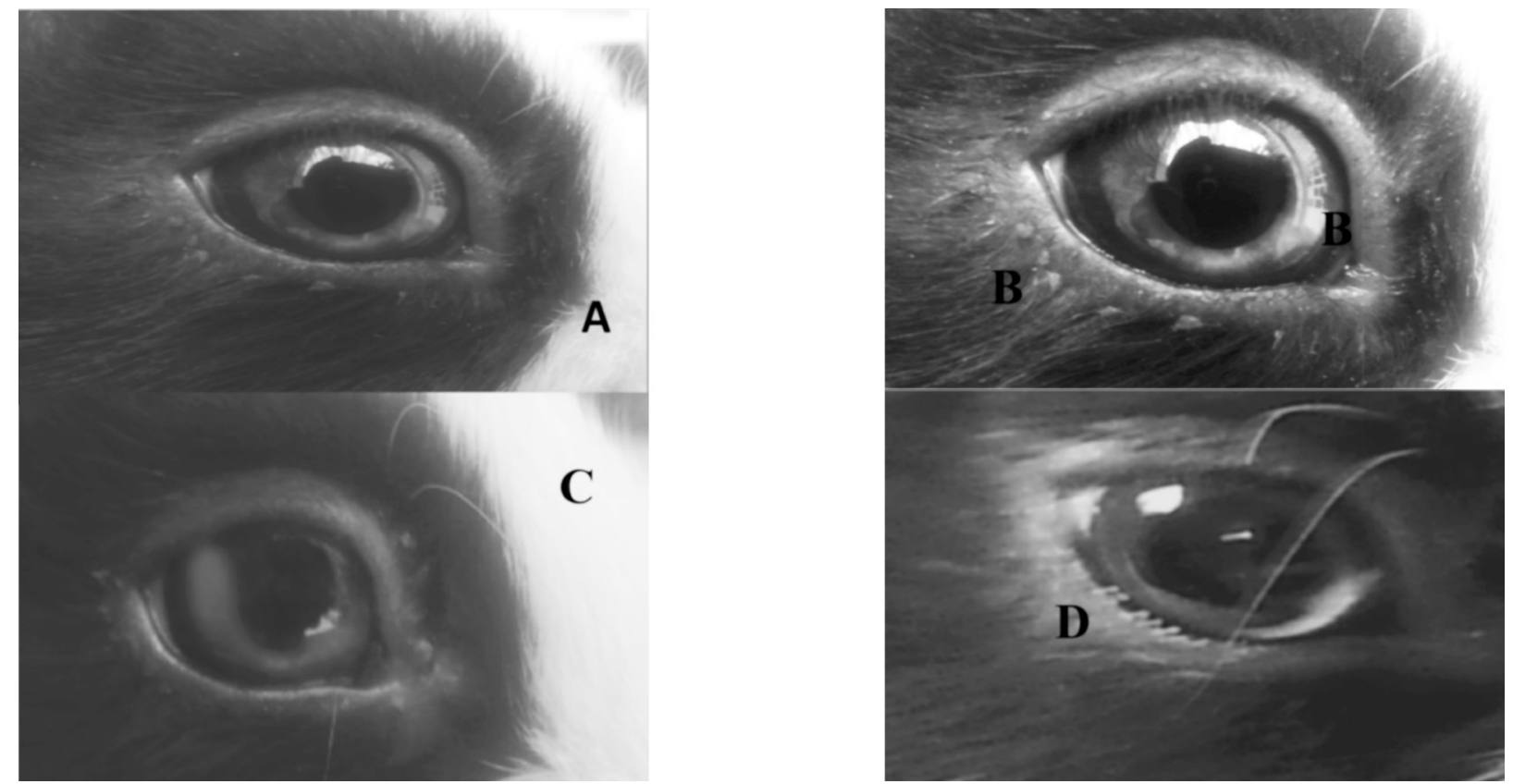

Figure ( 5. A .B. C. D) : A. B. Showed that cornea of the right eyes of rabbits after $15 \mathrm{~h}$ of topical treatment with LasA protease and Lysostaphin drug respectively ( give good potency of treatment of infection after this period ).C. Cornea of the rabbit after $15 \mathrm{~h}$ of topical treatment with Vancomycin drug ( give pad potency after this period ). D. Cornea of the same rabbit after three days of treatment with Vancomycin drug ( show good potency of treatment the infection). 


\section{Disccusion:}

Bacterial proteases constituted one of the largest classes of industrial enzymes and accounting for $40 \%$ of the total worldwide enzyme sales (17).Some types of protease such as (LasA protease) are not major virulence factor in experimental P. areuginosa keratitis, therefore, these enzymes have a protective effect against other bacterial keratitis caused by Staphylococcus aureus. LasA, an enzyme possessing an staphylolytic activities. LasA is able to cleave the pentaglycine bonds in peptidoglycan of S. aureus. This protease has been projected to be an ocular virulence factor. However, more recent research, based on the high virulence LasA deletion mutants, has shown it not to be necessary for corneal virulence $(18,19,20)$.

Real time analysis were performed on all isolates of Pseudomonas aeruginosa by using of a set of pair primers of LasA gene. Our study has showed that only one isolate harbor LasA gene at percentage (3.8\%) and was named as (P85).LasA enzyme was extracted from bacterial isolate (P85) by cold centrifuge and purified by gel filtration chromatography.

By testing the effectiveness of the enzyme was concentrated in the third peak and in the fractions (52-58) with increased in the purification times and by reference to standard curve of BSA, the concentration of the enzyme was measured and reached $40 \mu \mathrm{g} / \mathrm{ml}$.

The present results disagree with previous study conducted by (21), where used gel filtration chromatography for purification of LasA protease enzyme by using Bio - Gel - P -30 and their results showed that the fractions $(7,22)$ have higher activity for LasA enzyme. Also our results are not consisted with previous findings that done by (23) obtained of four protein peaks by using ion exchang ( DEAE - Cellulose), and the peak No. 1 was showed the activity of enzyme. However our findings are agree with what reached by other researchers (16), when the ion exchange chromatography was performed by carboxymethyl cellulose, the amount of purified LasA protease was about $40 \mu \mathrm{g} / \mathrm{ml}$. The discovery that LasA protease is a potent staphylolytic protease (24), suggested that it might lend itself to the treatment of $\mathrm{S}$. aureus infections. The ability of LasA protease to eradicate S. aureus in vivo has not been documented to date in Iraq. Using experimental model of S. aureus keratitis in rabbits eyes, we showed for the first time in Iraq that LasA can kill S. aureus cells in vivo and established in potential as a tool in the management of S.aureus keratitis. Since the efficacy of Lysostaphin has been evaluated in a similar model of S. aureus keratitis (25), it was of interest to compare the efficacy of LasA protease with that of Lysostaphin.

Our present results disagree with previous study performed by (16), this study suggested that the ability of LasA protease to eradicate the Methicillin Sensitive Staphylococcus aureus( MSSA) from cornea was higher than that of Lystostaphin and the efficacy of LasA protease against the Methicillin Resistant Staphylococcus aureus ( MRSA) was either the same as that of Vancomycin ( early initiation of therapy) or higher than that of Vancomycin ( Late initiation of therapy) while the clinical scores for eyes treated with either LasA protease or Vancomycin were essentially the same.

\section{Author contributions:}

Aida H. Al - saa'edi : ( samples collection, practical part of study, data collection, analysis design and interpretation of results).

Munera CH. Al - Abaadi: ( study conception, data analysis, practical part of extraction of LasA protease enzyme and critical revision.

Jassim M. Karhoot: ( data analysis and critical revsion).

Samira Funtil : ( practical part of purification of LasA protease enzyme).

\section{References:}

1. Willicox, M. D. P. (2007). Pseudomonas aeruginosa infection and inflammation during contact lens wear: A Review. J. Optom. Vis. Sci. 84:273-278.

2. Shah, R.; Shah, M.; Khandekar, R. et al. (2008).Contact lens induced corneal ulcer management in a tertiary eye unit in Oman - A descriptive study. SQU Med. J. 8:283-90.

3. Green, M.; Apel, A. and Stapleton, F. (2008). Risk factors and causative organisms in microbial keratitis. J. Cornea. 27 (1): 22-27.( IVSL).

4. Kessler, E. and Ohman, D.E. (2004). Staphylolysin (LasA endopeptidase), Pp. 1001-1003. In A. Barrett, N. Rawlings, and J. Woessner, The handbook of proteolytic enzymes, $2^{\text {nd }} e d$. vol. 1. Elsevier Academic Press, Amsterdam, Netherlands.

5. Patron, R. L.; Climo, M. W.; Goldstein, B. P. and Archerv G. L.(1999). Lysostaphin treatment of experimental aortic valve endocarditis caused by a Staphylococcus aureus isolate with reduced susceptibility to vancomycin. Antimicrob.J.Age. Chemother.43:1754-1755.

6. Kessler, E. and Ohman, D.E. (2004). Staphylolysin (LasA endopeptidase), Pp. 1001-1003. In A. Barrett, N. Rawlings, and J. Woessner, The handbook of proteolytic enzymes, 2nd ed. vol. 1. Elsevier Academic Press, Amsterdam, Netherlands. 7. Alionte, L.G.; Canon, B.M.; White, C.D. et al. (2001). Pseudomonas aeruginosa LasA protease and corneal infections. J. Curr. Eye Res. 22:266-271.

8. Hobden, J.A. (2002). Pseudomonas aeruginosa proteases and corneal virulence DNA.J. Cell. Biol.21:391-396.(IVSL). 
9. Najafi, M.F. and Deobagkar, D. (2005). Potential application of protease from Pseudomonas aeroginosa. Electronic J. Biotechnol.8: 1-7.

10. Tille, P.M. (2014). Baily and Scott's, Diagnostic Microbiology. 13 ed . Elsever Mosby. Missouri, United States of America.

11. Diggle, S.P.; and Winzer, K.; Lazdunski, A. et al. (2002). Advancing the quorum in Pseudomonas aeruginosa: mva $T$ and the regulation of $N$-acylhomoserine lactone production and virulence gene expression. J. Bacteriol. 184(10):25762586 .

12.Bayoudh, A.; Chamkha, M.; Dhouib, A. et al. (2000). Purification and characterization of an alkaline protease from Pseudomonas aeruginosa MN1. J. Indus. Microbiol. Biotech.24:291-295.

13. Bradford, M.M.(1976). A rapid and sensitive method for the quantitation of microorganism quantities of protein utilizing the principle of protein - dye-binding. J. Anal. Biochem. 72:248-254.

14. Deng A, WU J, Zhang Y, Zhang G. et al. (2010). Purification and characterization of a surfactant-stable high-alkaline protease from Bacillus sp. B001. Bioresour. Technol. 101: 7100-7116.

15. Morihara, K. and Tsuzuki, H. (1977). Production of protease and Elastase by Psedomonas aeruginosa strains isolated from patients. Infect. Immune.15 (3): 679-685.

16. Barequet, I.S.; Guy, J. B.; Safrin, M. et al. (2004). Pseudomonas aeruginosa LasA Protease in Treatment of Experimental Staphylococcal Keratitis. J. ASM. Org. Antimicrob. Age. Chemother.48(5): 1681.

17. Patil,U. and Chaudhari, A. (2009). Purification and characterization of solvent - tolerant ,thermostable, alkaline metalloprotease from alkalophilic Pseudomonas aeruginosa.J.Chem.Techno. Biotechnol.84: 1255-1262.

18. Bharathi, M.J.; Ramakrishanan, R.; Meenakshi, R. et al. (2007): Microbial keratitis in South India: Influence of risk factors, climate, and geographical variation. J. Ophthalmic Epidemiol.14:16-69.

19. Vessillier, S.; Delolme, F.; Bernillon, J. et al. (2001). Hydrolysis of glycine - containing elastin pentapeptidase by LasA, ametallo elastase from Pseudomonas aeruginosa. Eur. J. Biochem. 268:1049-1057.

20.Toder, D.S.;Gambello,M.J. and Iglewski BH. (2010). Pseudomonas aeruginosa LasA: a second elastase under the transcriptional control of lasR. Mole. Microbiol. 62:13201327.

21. Park, P.W.; Pier, G.B.; Preston, M.J. et al. (2000). Syndecan -1 shedding is enhanced by LasA, a secreted virulence factor of Pseudomonas aeruginosa. J. Biol. Chem. 275(5): 3057-3064.
22. Preston, M. J.; Seed,P. C.; Toder,D. et al. (1997). Contribution of proteases and LasR to the virulence of Pseudomonas aeruginosaduring corneal infections. J. Infect. Immun. 65:3086-3090.

23. Kadhim, I. J. (2008): Role of proteases produced by Pseudomonas aeruginosa in corneal ulcer (keratitis). PhD. Thesis. College of Science / Baghdad University.

24. Kessler, E.; Safrin, M.; Olson, J.C et al. (1993). Secreted LasA protease of Pseudomonas aeruginosa is a staphylolytic protease. J. Biol. Chem. 268: 7503-7508. [Pub Med].

25. Dajcs, J. J.; Thibodeaux, B. A.; Girgis, D. O. et al. (2002). Immunity to lysostaphin and its therapeutic value for ocular MRSA infections in the rabbit. Invest. Ophthalmol. Vis. Sci. 43:3712-3716. 